Ann. génét. sél. anim., I978, 10 (3), 343-351.

\title{
Genetic formulas for the colour in the Texel, the Dutch and the Zwartbles sheep in the Netherlands
}

\author{
J. J. LAUVERGNE and P. HOOGSCHAGEN \\ Département de Génétique animale \\ Centre national de Recherches zootechnique, I.N.R.A., \\ 78350 Jouy-en-Josas, France \\ Directie Veehouderij en Zuivel, \\ Ministerie van Landbouw en Visserij, \\ Bezuidenhoutseweg 73, Gravenhage, Nederland
}

\section{Summary}

The Texel sheep of the Netherlands, as well as the common sheep we have called Dutch, are usually white. Their most frequent formula for the three loci of coloration Agouti $(A)$, Extension $(E)$ and Irregular Spotting $(S)$ is $A^{w h} A^{w h} E+E+S+S^{+}$, where $A^{\text {wh }}$ is a gene for light tan or white.

The blacks segregating in Texel are given by the recessive $a$ (black) in Agouti.

The black sheep found in Dutch sheep, on the contrary, are usually $A^{w h} A^{w h} E^{d} E^{+}$(or $E^{d} E^{d}$ ) $S^{+} S^{+}$. The black pigmentation being due to the dominant $E^{d}$ allele in $E$ which is epistatic on A gouti genotypes.

The Zwartbles which is black with white stripe in head, white socks and white tip of tail (HST) has a formula which is probably $A^{w h} A^{w h} E^{d} E^{d}$ (or $\left.E^{d} E^{+}\right) S^{b} S^{b}$ where $S^{b}$ is the allele for HST or Bizet design. and .o3o.

The frequency of $a$ in Texel sheep is around .or 8 that of $E^{d}$ in Dutch sheep lies between .or 5

\section{Introduction}

According to HAGEDOORN and HAGEDOORN (I9I4) the black coloration segregating in white flocks in the Netherlands was due to a gene recessive to a gene for white.

Nevertheless a note by KALSBEEK (I963) seemed to indicate that a dominant type of inheritance for the black was also present in the sheep of the Netherlands and this was confirmed by HoogschaGEN (I963).

Later on data were collected among breeders in the Netherlands (HoogschaGEN, I964) and presented in two articles: one of which was devoted to hereditary 
transmission of white markings on black background (HoOGSCHAGEN, I966) and the other had to do with the two types of black (recessive and dominant), HOOGSCHAGEN (1967).

Since that time additional information has been presented concerning the transmission of coat color in Sheep. In this article a consideration will be given to a more accurate interpretation of the in heritance of coat colour in the Netherland sheep.

\section{I. - Material and methods}

\section{A. - The breeds}

According to the May-census there were in 1977 about 800 ooo heads of sheep in the Netherlands, thereof about 330000 mature ewes and 450000 lambs.

We have considered three breeds of the Netherlands: the Texel, the Dutch and the $Z$ wartbles sheep.

The Texel is a registered white breed originating from the Texel island, with about 60 ooo ewes registered.

The Dutch sheep is the name we propose in this article to the non-registered common sheep. It presents many similarities with the Texel as many Texel rams are among its progenitors. The number of Dutch sheep can be estimated on 250000 ewes, most of them are white, about Io to 15000 are black.

The so-called $Z$ wartbles breed gathers flocks of black sheep deriving from Dutch populations and wears the white design sometimes called HS'T (white head, spotted socks, white tail tip). The number can be estimated between I ooo and 2 ooo. It is in extension with the need for black wool for handicraft.

\section{B. - The observed colorations}

The color standard of the Texel is a white, which presents some melanisation on the muzzle and around the eyes (fig. $\mathrm{x} a$ ).

The black animals in Texel or in Dutch sheep are usually totally black. There are some cases of HST in Dutch sheep and even of more extended piebaldness (fig. Ib.c.d).

The $Z$ wartble sheep are black with HST, as said before (fig. Ic).

\section{C. - The data of segregation}

The data are those already presented by KAL,SBEEK (I963) and HOOGSCHAGEN $(\mathrm{rg} 63, \mathrm{rg66}, \mathrm{rg67})$ plus those resulting from a survey in pure Texel Sheep and others recently gathered by one of us $(\mathrm{P} . \mathrm{H}$.).

In order to measure the economical importance of breeding black sheep in the Netherlands we have checked the observations of the Netherlands Wool Board (Coöperatieve Nederlandse Wolfederatie G.A. ${ }^{*}$ ) which commercializes more than 50 p. roo of domestic wool.

(*) Address : Helderseweg 32, Alkmaar. 

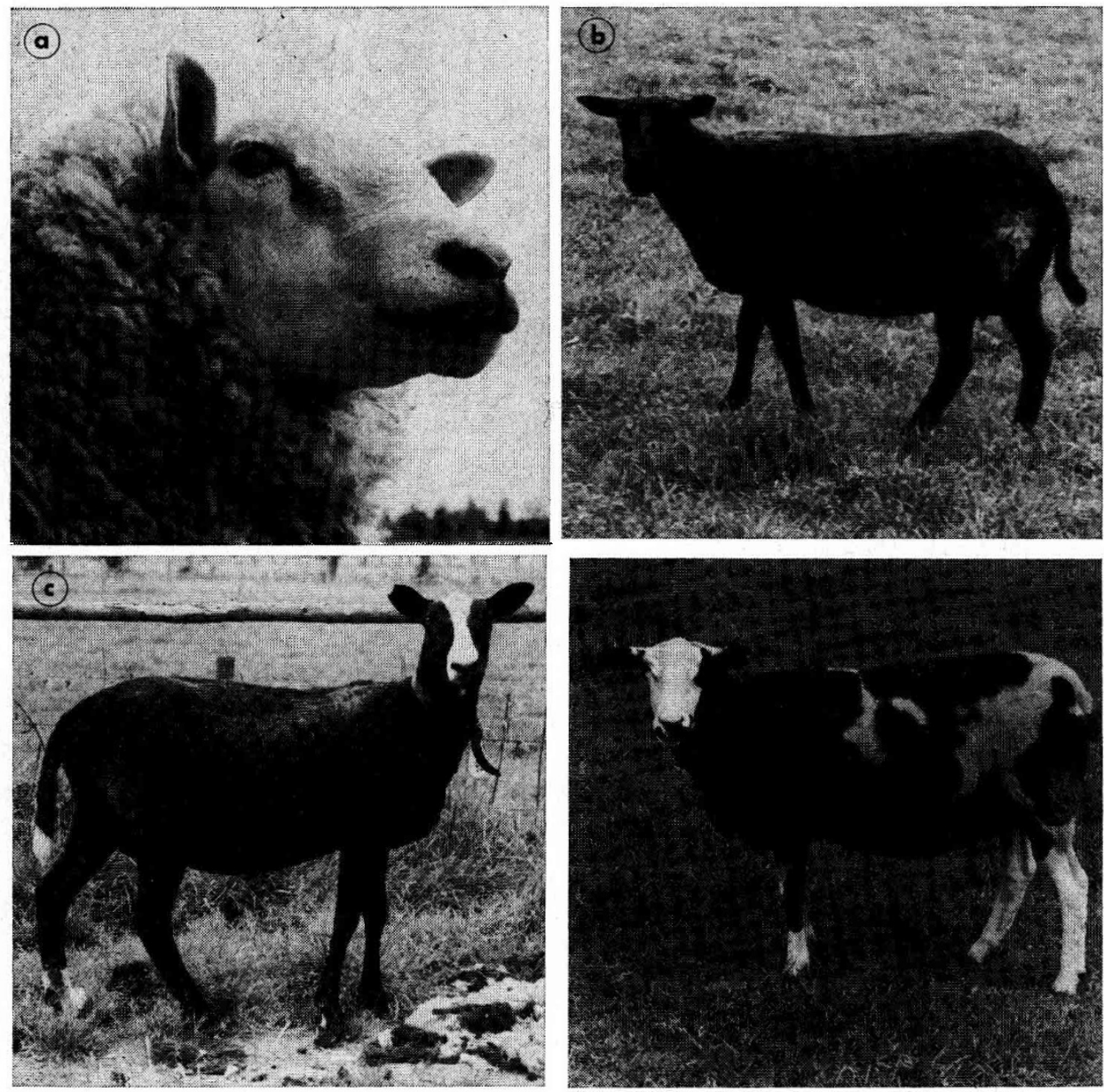

FrG. I. - Observed coloration

a) Head of a white Texel ewe - one can see the melanisation on the muzzle and around the eye.

b) Black ewe as observed in Dutch Sheep.

c) HST design observed in Zwartbles and in some black Dutch.

d) Extended piebaldness sometimes seen in black Dutch sheep.

FIG r. - Les couleurs observées

a) Tête d'une brebis Texel blanche - on distingue la mélanisation sur le museau et autour de l'œil.

b) Brebis noire en race Dutch.

c) Le dessin HST du Zwartbles et de quelques Dutch noirs.

d) Extension de la panachure quelquefois rencontrée chez les Dutch noirs.

\section{II. - Results}

The results of crossings are presented in table $I$ and 2. Table $I$ is devoted to the analysis of black versus white, table 2 to the segregation of piebaldness. 
TABLEAU I

Crossing between black and white Sheep of Texel and Dutch breed Résultats de croisements entre moutons Texel et Dutch noirs et blancs

\begin{tabular}{|c|c|c|c|}
\hline $\begin{array}{l}\text { Cross- } \\
\text { ing } \\
\text { No }\end{array}$ & Parents & Progeny & Place, time, references \\
\hline I & White pure bred Texel & $\begin{array}{l}\text { Some black are seen from } \\
\text { time to time }\end{array}$ & $\begin{array}{l}\text { HAGEDOORN and HAGEDOORN } \\
(\text { I9I4) }\end{array}$ \\
\hline 2 & White pure bred Texel & $\begin{array}{l}\text { Four black lambs among } \\
\text { about I3 ooo births }\end{array}$ & $\begin{array}{l}\text { Survey in Texel pure bred flocks } \\
\text { in Texel island (1977) }\end{array}$ \\
\hline 3 & $\begin{array}{l}\text { Black Dutch } \delta \times \text { white } \\
\text { Dutch } \text { \&ᄋ }\end{array}$ & 22 black, o white & KAISSBEEK (1963) \\
\hline 4 & $\begin{array}{l}\text { Black Dutch o } \times \text { white } \\
\text { Dutch } \text { 오 }\end{array}$ & Only black & $\begin{array}{l}\text { In De KRUIF flock, de Bilt (Utr.), } \\
\text { (1977) }\end{array}$ \\
\hline 5 & $\begin{array}{l}\text { Black Dutch o } \times \text { white } \\
\text { Dutch 우 }\end{array}$ & $\begin{array}{l}\text { About the same number } \\
\text { of white and black }\end{array}$ & HOOGSCHAGEN (1967) \\
\hline 6 & $\begin{array}{l}\text { White Dutch } \sigma^{*} \times \text { black } \\
\text { daughers of } 5\end{array}$ & $\begin{array}{l}\text { About the same number } \\
\text { of white and black }\end{array}$ & HOOCGSCHAGEN ( 1967 ) \\
\hline 7 & $\begin{array}{l}\text { White Dutch of } \times \text { black } \\
\text { daughters of } 6\end{array}$ & $\begin{array}{l}\text { About the same number } \\
\text { of white and black }\end{array}$ & HOOGSCHAGEN $(1967)$ \\
\hline 8 & $\begin{array}{l}\text { Black Texel ơ } \times \text { Zwart- } \\
\quad \text { bles }\left({ }^{(1)} \text { 우오 }\right.\end{array}$ & I7 black, I white & $\begin{array}{l}\text { In Van den BuRG flock, Jelsum } \\
\text { (Friesland) } \\
\text { HOOGSCHAGEN }(1967)\end{array}$ \\
\hline 9 & $\begin{array}{l}\text { Black ơ from } 8 \times \text { black }+ \text { o } \\
\text { from } 8\end{array}$ & 7 black, 2 white & Id. 8 \\
\hline IO & $\begin{array}{l}\text { Black Texel } ठ \times \text { white } \\
\text { from } 8\end{array}$ & I black, I white & Id. 8 \\
\hline II & $\begin{array}{l}\text { Black ơ for from } 8 \times \text { white } \\
\text { Texel } \text { 우 }\end{array}$ & $3^{8}$ black, $3^{2}$ white & $\begin{array}{l}\text { In C. HoogschaGEN's flocks, } \\
\text { Julianadorp (North Holland) } \\
\text { HOOGSCHAGEN (I967) }\end{array}$ \\
\hline
\end{tabular}

(1) Black with HST markings.

The frequency of black wools in the Netherlands for the years I97I to 1976 is given in the table 3 .

\section{Discussion}

\section{A. - Recall of the genetics of white and black in Sheep}

I) White

The existence of two black factors: one acting as a dominant, the other as a recessive towards white, has been described for years in the Sheep (see RAE, I956 for a review). For a geneticist in mammalian coloration it is rather puzzling 
TABLEAU 2

Segregations of HST markings among black animals in different crosses with the test of HST being due to a recessive gene $\left({ }^{1}\right)$

Ségrégation du dessin HST parmi les animaux noirs dans différents croisements et test de l'hypothèse d'un récessif donnant HST

\begin{tabular}{|c|c|c|c|c|c|c|c|c|}
\hline \multirow{3}{*}{$\begin{array}{c}\text { Cross } \\
\text { No }\end{array}$} & \multicolumn{2}{|c|}{ Parents } & \multicolumn{4}{|c|}{ F I } & \multirow{3}{*}{$\chi^{2}$} & \multirow{3}{*}{ Flocks } \\
\hline & \multirow{2}{*}{ ठేర } & \multirow{2}{*}{ 우 } & \multicolumn{2}{|c|}{ Solid black } & \multicolumn{2}{|c|}{ HST } & & \\
\hline & & & $\begin{array}{c}\text { Ex- } \\
\text { pected }\end{array}$ & $\begin{array}{c}\text { Ob- } \\
\text { served }\end{array}$ & $\begin{array}{c}\text { Ex- } \\
\text { pected }\end{array}$ & $\begin{array}{c}\text { Ob- } \\
\text { served }\end{array}$ & & \\
\hline I & $\begin{array}{r}\text { Solid black } \\
\text { Texel } \\
\mathrm{S}+\mathrm{S}^{+}\end{array}$ & $\begin{array}{c}\text { Zwartbles } \\
S^{b} S^{b}\end{array}$ & I 7 & 17 & o & o & $\begin{array}{ll}0 & \mathrm{NS}\end{array}$ & $\begin{array}{c}\text { Van den BURG, } \\
\text { Jelsum (Fr) }\end{array}$ \\
\hline 2 & $\begin{array}{c}\text { Solid black } \\
\text { from I } \\
S+S^{b}\end{array}$ & $\begin{array}{c}\text { White Dutch } \\
S^{+} S^{+}\end{array}$ & $3^{8}$ & $3^{8\left({ }^{(1)}()^{2}\right)}$ & o & o & $\left|\begin{array}{ll}0 & \mathrm{NS}\end{array}\right|$ & $\begin{array}{l}\text { C. Hoogscha- } \\
\text { GEN Juliana- } \\
\text { dorp (N.H.) }\end{array}$ \\
\hline 3 & $\begin{array}{l}\text { Solid black } \\
\text { from I } \\
S^{+} S^{b}\end{array}$ & $\begin{array}{c}\text { Zwartbles } \\
S^{b} S^{b}\end{array}$ & 4.5 & 6 & $4 \cdot 5$ & 3 & $\begin{array}{ll}\mathrm{I} & \mathrm{NS}\end{array}$ & $\begin{array}{l}\text { WENNEMARS, } \\
\text { Dalisen (Ov.) }\end{array}$ \\
\hline 4 & $\begin{array}{c}\text { Solid black } \\
\text { from I } \\
S+S^{b}\end{array}$ & $\begin{array}{c}\text { Solid black } \\
\text { from I } \\
S^{+} S^{b}\end{array}$ & 5.25 & 5 & I. 75 & 2 & $0.47 \mathrm{NS}$ & $\begin{array}{l}\text { Van den BURG, } \\
\text { Jelsum (Fr.) }\end{array}$ \\
\hline
\end{tabular}

(1) Data from Hoogschagen, I966.

(2) Some animals have a few white hair or a little white spot on the forehead.

as, usually, black may not be obtained by alleles of loci giving white designs as these genes act only as suppressors of any kind of pigmentation (SEARLE, I968). Moreover it is hardly to admit a dominant black as well as a recessive one being at the same locus.

Nevertheless it has been shown that an allele in A gouti may play the role of a white gene. This is the case for the allele $A_{1}$ of Adalsteinsson (I970) further on (r974) named $A$ wh by the same author. This factor induces a tan pigmentation (black or brown eumelanin being suppressed) which at its turn may turned offset, giving pure white. This offseting is apparently due to modificater genes which may lead to pure white breeds.

Later on LAUVERGNE (I976) studying in France various crosses between deep red Solognot, white Berrichon, black with HST Bizet and a black and tan HTS Finish ram has shown that, in this situation, a modificator gene for obtaining pure white from a red allele in Agouti was the piebald HST gene called $S^{n}$ 


\section{TABLEAU 3}

Frequency of black wool in percentage of total weight commercialized by the Netherlands Wool Board Fréquence des laines noires aux Pays-Bas en pourcentage du poids total commercialisé par l'Office néerlandais de la laine

\begin{tabular}{|c|c|c|c|c|c|c|c|c|}
\hline & \multirow{2}{*}{ Provinces } & \multicolumn{7}{|c|}{ Years } \\
\hline & & $197^{\circ}$ & I97I & I972 & I973 & I974 & 1975 & I976 \\
\hline $\begin{array}{l}\text { Groningen . . } \\
\text { Friesland . } \\
\text { Drenthe . } \\
\text { Overijssel . } \\
\text { Gelderland . } \\
\text { Utrecht . . } \\
\text { North-Holland } \\
\text { South-Holland } \\
\text { Zeeland . . . } \\
\text { North-Brabant } \\
\text { Limburg . . }\end{array}$ & 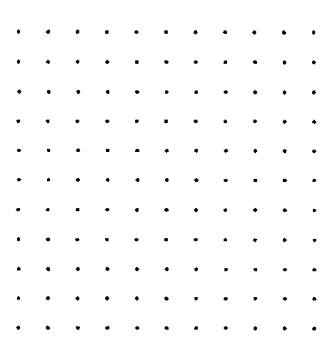 & & $\begin{array}{l}3 \\
4 \\
4 \\
3 \\
3 \\
4 \\
\mathrm{I} \\
4 \\
\mathrm{I} \\
3 \\
\mathrm{x}\end{array}$ & $\begin{array}{l}3 \\
3 \\
3 \\
3 \\
2 \\
4 \\
\mathrm{I} \\
5 \\
\mathrm{I} \\
3 \\
\mathrm{I}\end{array}$ & $\begin{array}{l}3 \\
3 \\
4 \\
3 \\
2 \\
3 \\
\mathrm{I} \\
5 \\
\mathrm{I} \\
2 \\
\mathrm{I}\end{array}$ & $\begin{array}{l}2 \\
2 \\
3 \\
3 \\
3 \\
3 \\
1 \\
5 \\
\mathrm{I} \\
2 \\
\mathrm{I}\end{array}$ & $\begin{array}{l}2 \\
2 \\
2 \\
2 \\
2 \\
2 \\
\mathrm{I} \\
4 \\
0 \\
\mathrm{I} \\
0\end{array}$ & $\begin{array}{l}\text { I } \\
\text { I } \\
\text { I } \\
\text { I } \\
\text { I } \\
2 \\
\text { I } \\
2 \\
0 \\
\text { I } \\
0\end{array}$ \\
\hline All country & 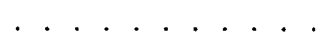 & 2,02 & 2,46 & $2,2 \mathrm{I}$ & 2,12 & $\mathrm{I}, 99$ & $\mathrm{I}, 5^{\circ}$ & 0,98 \\
\hline
\end{tabular}

(ADALSTEINSSON's I974 s). Whose behaviour was very different according the pigmentary background. This red allele was nemed $A^{\text {wh }}$ but one can wonder if it is the same as Adalsteinsson's one.

2) Recessive black

White being explained by an allele in $A$ gout $i$ the recessive black is, as in may Mammals, the recessive term of this allelic series.

\section{3) Dominant black}

Reviewing previous works, specially those by ROBERTS (I924), ROBERTS and WHITE (I930) and ZOPHONIASSON (I934) and taking account of the homology between colour loci in Mammals RENDEL (I957) was the first author to consider the dominant black gene in the Sheep to be an allele at the Extension $(E)$ locus. This interpretation supposes that $E^{d}$ is not only dominant upon $E^{+}$but also epistatic on any kind of allelic combination in Agouti locus. Recently one of us (LAUVERGNE, I976) has analysed data with the two type genetic factors for the black, with that scope in mind.

\section{B. - Interpretation of our data}

I) The white colour and the recessive black

According the above considerations the white of Texel could result of the action of an allele in Agouti dominant towards the recessive black $a$. As the blacks segregating are solid black the gene for HST $S^{b}$ is apparently absent from the breed. 
One can admit that the $A$ gouti allele for white is $A$ wh as in Iceland, provide one considers that, in some cases this factor for tan may allow some black pigmentation on the muzzle and around the eyes as in the white Gotland sheep described by LöFVENBERG and JOHANSSON (1952).

The formula of white Texel becomes $A^{\text {wh }} A^{\text {wh }} S^{+} S^{+}$or $A^{\text {wh }} a S^{+} S^{+}$, as some recessive blacks $a a S^{+} S^{+}$are sometimes produced. The formula of white Dutch is probably identical to that of white Texel.

\section{2) The dominant black}

The crosses no $3,4,5,6,7$ and II demonstrate the existence of a dominant black, the black parents being homozygotes as in 3 and 4 or heterozygotes as in 5, 6, 7 and II (resp. $A^{w h} A^{w h} E^{d} E^{d}$ and $A^{w h} A^{w h} E^{d} E^{+}$).

The crosses 8,9 and Io, show that the two genes for black, dominant and recessive, are definitely non allelic.

\section{3) The white marks on black background}

The hereditary transmission of HST among pigmented animals appears monofactorial recessive as tested in table $2: s^{b}<S^{+}$. Some very thin dominancy (white hair on the forehead) may be detected in some heterozygotes.

These interpretations concerning heredity of pigmentation and of white markings are summarized in table 4 .

\section{TABLEAU 4}

Genetic formula proposed for the various phenotypes observed in Dutch, Texel, and Zwartbles sheep in the Netherlands

Formules génétiques proposées pour les divers phénotypes observés en races ovines Dutch, Texel et $Z$ wartbles aux Pays-Bas

\begin{tabular}{|c|c|c|c|c|}
\hline Breed & $\begin{array}{l}\text { Agouti } \\
\text { locus } A\end{array}$ & $\begin{array}{l}\text { Extension } \\
\text { locus } E\end{array}$ & $\begin{array}{l}\text { Irregular spotting } \\
\text { locus } S\end{array}$ & $\begin{array}{l}\text { Formulas given } \\
\text { by HoOGSCHAGEN, } \\
\text { I963, I966, I967 }\end{array}$ \\
\hline Texel & $\begin{array}{l}A^{w h} A \text { wh or } \\
A^{w h} a\left(^{1}\right)\left({ }^{2}\right)\end{array}$ & $E+E+$ & $\begin{array}{r}S+S+\text { or } \\
S^{+} S^{b}\left({ }^{2}\right)\end{array}$ & $\begin{array}{c}W W z z \text { or } \\
W w z z\end{array}$ \\
\hline $\begin{array}{l}\text { Black segregating in } \\
\text { Texel flock }\end{array}$ & $a a$ & $E+E+$ & $\begin{array}{c}S+S+\text { or } \\
S+S^{b}\left({ }^{2}\right)\end{array}$ & $w w z z$ \\
\hline White Dutch & $\begin{array}{l}A^{w h} A^{w h} \text { or } \\
A^{w h} a\left(^{1}\right)\left(^{2}\right)\end{array}$ & $E+E+$ & $\begin{array}{c}S+S+\text { or } \\
S+S^{b}\left({ }^{3}\right)\end{array}$ & $\begin{array}{c}W W z z \text { or } \\
W w z z\end{array}$ \\
\hline Black Dutch & $\begin{array}{c}A^{w h} A^{w h} \text { or } \\
A^{w h} a\left({ }^{2}\right)\end{array}$ & $\begin{array}{c}E^{d} E^{d} \text { or } \\
E^{d} E^{+}\end{array}$ & $\begin{array}{c}S+S+\text { or } \\
S+S^{b}\end{array}$ & $\begin{array}{l}W W Z Z \text { or } \\
W W Z z\end{array}$ \\
\hline Zwartbles (HST) & $\begin{array}{c}A^{w h} A \text { wh or } \\
A^{w h} a\left({ }^{2}\right)\end{array}$ & $\begin{array}{c}E^{d} E^{d} \text { or } \\
E^{d} E^{+}\end{array}$ & $S^{b} S^{b}$ & $W W Z Z n n$ \\
\hline
\end{tabular}

(1) When they gave black lambs.

(2) Rare.

(3) Rather rare. 
It may seem strange that the black is due in two closely related breeds in the same country to different genetical formulas. This is apparently due to the fact that only white Texel rams are raised and sailed out, which prevents the spreading out of the recessive black $a$. On the other hand in Dutch breed it is easier to obtain black offspring with a ram wearing a dominant black.

\section{C. - Comparison with previous interpretations}

An hypothesis with two independant factors for the black was already brought by one of us (HoogschaGen, I963) : $W / w$ (w $=$ recessive black) and $Z / z(Z=$ dominant black). For statistical tests there is no difference between this hypothesis and the present interpretation. But, if the alternative $W / w$ fits well with $A / a$, the dominant black $Z$ upon a white $z$ does not correspond exactly to the new interpretation. The relationship of $E^{d}$ towards white, as a matter of fact, is not of dominancy but of epistacy. The allele $E^{d}$ gives a black coloration whichever the formula in $A$ gouti may be and is dominant on $E^{+}$whose behaviour is simply to allow the normal expressivity of genotypes in Agouti locus.

For the piebald gene giving HST there is a close corresponding between Hoogschagen's $n$ (I966) and $s$ or $S^{b}$ (ADALSTEINSSON I974, LAUVERGNE I976).

\section{D. - The frequency of different alleles for the black color}

With the data of the survey in pure Texel breed ( 4 in $\mathrm{I}_{3}$ 00o) one can estimate the frequency of the gene $a:\left(q_{a}=0.018\right.$ in that breed).

The data of table 3 show that the frequency of pigmented wool is about 2 p. Ioo (established on seven years). According the experts this value must be majored of at least I point, as a greater part of black wool is not checked by the Wool Board, as it is used for handicraft.

If all the klack sheep on Dutch breed are homozygote the frequency of the gene $E^{d}$ is 0.03 . In case all are heterozygotes the frequency is only o.or5. The frequency lies probably somewhere between these two figures.

\section{Conclusion}

Two genetical types of black do exist in the sheep in the Netherlands. One is given by the recessive a allele in $A$ gouti; the other by a dominant allele $E^{d}$ in Extension, which is epistatic on Agouti genotypes.

Reçu pour publication en décembre 1978 .

\section{Résumé}

Formules génétiques pour la couleur des moutons, Texe1, Dutch et Zwartbles aux Pays-Bas

Le mouton Texel des Pays-Bas, au même titre que le mouton commun de ce pays que nous avons appelé $D$ utch, est généralement blanc. La fosmule la plus fréquente aux trois loci de coloration Agouti $(A)$, Extension $(E)$ et Panachure Irvégulière $(S)$ est $A^{\text {wh }} A^{\text {wh }} E+E+S+S+$ ò̀ $A^{\text {wh }}$ est le gène pour le fauve ou le blanc. 
Les animaux noirs ségrégant en Texel portent l'allèle recessif a (noir) en $A$ gouti.

Les agneaux noirs qui naissent dans la race $D u t c h$ sont, au contraire, généralement $A^{\text {wh }} A^{\text {wh }} E^{d}$ $E^{+}$(ou $\left.E^{d} E^{d}\right) S+S+$. La pigmentation noire est due à l'allèle dominant $E^{d}$ au locus $E$, allèle qui est épistatique sus les génotypes en $A$ gouti.

Le Zwartbles qui est noir avec une liste blanche en tête, des socquettes et le bout de la queue blancs (dessin blanc dit HST) a probablement la formule $A^{\text {wh }} A^{\text {wh }} E^{d} E^{d}$ (ou $E^{d} E^{+}$) $S^{b} S^{b}, S^{b}$ étant l'allèle pour le dessin HST ou Bizet.

La fréquence de $a$ en race Texel est aux alentours de 0,018 celle de $E^{d}$ du mouton $D u t c h$ est comprise entre 0,015 et 0,030 .

\section{References}

Adalsteinsson S., 1970. Colour inheritance in Icelandic Sheep and relation between colour, fertility and fertilization. J. Agr. res. Icel., 2, 3-1 35 .

AdALSTEINSSON S., r974. Colour inheritance in farm animals and its application in selection. Irst World Congr. Genet. appl. Livest. Prod., 1, 29-37.

HAGEDOORN A. L., HAGEDOORN A. C., I914. Studies in variation and selection. Z.indukt. Abst. VeverbsLehr., 15, $145-183$.

HoogschaGen P., r963. De vererving van de zwarte kleur bij onze schapen : fokken in de duisternis (Transmission of black colour in sheep : breeding in the darkness.) Het Schaap, 7 (4).

HOOGSCHAGEN P., 1964. Zwarte schapen (Black sheep). Het Schaap, 8 (2).

Hoogschagen P., 1966. Over de vererving van witte en zwarte wol bij onze Nederlandse schapen, over blesschapen en over zwarte en bleke bekken (Transmission of white and black whool by Netherlands sheep: about zwartbles-sheep, and about black and white mouths in sheep). Het Schaap, 10 (3).

Hoogschagen P., 1967. De vererving van de zwarte kleur bij Nederlandse schapen (Tsansmission of black colour by Netherlands sheep). Veeteelt Zuivelber., 10, 22-27.

KALSBEE K K., I963. Fokken in de duisternis (Breeding in the darkness). Het Schaap, 7 (3).

LAUVERGNe J. J., I969. Hérédité de la couleur blanche de mouton Berrichon croisé à des Solo gnots. Ann. Génét. Sél. anim., 1, 219-226.

LAUVERGNe J. J., I975. Génétique de la couleur de la toison de trois races ovines françaises : Berrichonne, Bizet et Solognote. Ann. Génét. Sél. anim., 7, 263-276.

LöFVENBERG S., JohansSON I., I952. Über die Farbenvererbung beim gotländischen Landschaft. Z. Tierzucht. Zuchtungs Biol., 60, 253-262.

RAE A. L., 1956. The genetics of the Sheep. Adv. Genet., 8, I89-265.

RENDEL, I., r957. Nedärving av färg och teckning hos husdjur (Heredity of colour and piebaldness in livestock). Kungl. Skogs. Landbruksakad. Tidskr., 96, 208-263.

ROBERTS J. A. F., I924. Colour inheritance in Sheep. I. Black colour and badger face pattern in Welsh-Mountain Sheep. J. Genet., 14, 367-374.

Roberts J. A. F., White R. G., I930. Colour inheritance in Sheep. V. Dominant black. J. Genet., 22, I 8 I-I9o.

SEARLE A. G., 1968. Comparative genetics of coat colour in Mammals. Logos Press, Academic Press, London and.

Zophoniasson P., 1934. Nogle Bemaerkninger om enkelte Arvelighedsforhold hos de islandske Faar. Nord. Jordbrugsforskn., 16, 21 7-223. 